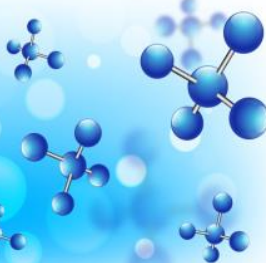

\title{
Relationship Between Prenatal and Perinatal Factors with the Incidence of Mental Retardation Among Children in Padang City 2017
}

\section{Marzatia Yulika $^{1 *}$, Yusrawati ${ }^{2}$, Ulvi Mariati ${ }^{3}$}

${ }^{1}$ Bachelor of Midwifery Program Faculty of Medicine Andalas University Jln. Niaga no. 56 Padang, Indonesia

${ }^{2}$ Bachelor of Midwifery Program Faculty of Medicine Andalas University Jln. Niaga no. 56 Padang, Indonesia

${ }^{3}$ Bachelor of Midwifery Program Faculty of Medicine Andalas University Jln. Niaga no. 56 Padang, Indonesia

\begin{tabular}{l}
\hline SUBMISSION TRACK \\
\hline Recieved: Oktober 28, 2017 \\
Final Revision: Nopember 03, 2017 \\
Available Online: Desember 15, 2017 \\
KEYwORDS \\
\hline Mental retardation, prenatal factor, perinatal factor \\
CORRESPONDENCE \\
\hline E-mail: author@email.com
\end{tabular}

E-mail: author@email.com

\section{A B $\quad$ S T T R A C T \\ Mental retardation is a condition of intellectual function that is below the average before the age of 18 years. Almost 83 million people around the world are estimated to have mental retardation. With 41 million have long term mental disability. Although the main cause of mental retardation is still fully unknown, prenatal and perinatal factors are suspected to be the risk factors for this. This study aims to determine the relationship between prenatal and perinatal factors with the incidence of mental retardation among children in Padang City.}

This was an observational analytic study with case control design. Population of this study divided into two, the case population ( all mothers of mentally retarded child) and control population (all mothers of normal children). The sample was 49 people taken by cluster sampling with the comparison case : control (1:1). Data collected by questionnaire. Data analysis was performed using Chi Square.

The result of this study showed that there is a significant relationship between prenatal and perinatal factors such as maternal age $(\mathrm{OR}=8.4 ; \quad 95 \% \quad \mathrm{CI} \quad 2.8-24.9 ; \quad \mathrm{P}=<0.001)$, father's age $(\mathrm{OR}=2.4 ; 95 \%$ CI $1.1-5.6 ; \mathrm{P}=<0.043)$, parity $(\mathrm{OR}=4.01 ; \quad 95 \% \quad$ CI $\quad 1.7-9.4 ; \quad \mathrm{P}=<0.002), \quad$ asphyxia $(\mathrm{OR}=23.2 ; 95 \%$ CI 2.9-184.1; $\mathrm{P}=<0.001)$ and birth weight ( $\mathrm{OR}=9.3 ; 95 \%$ CI 1.1-78.04; $\mathrm{P}=<0.031$ ) with the incidence of mental retardation. Factors which does not have a significant relationship in this study are hypertension in pregnancy $(\mathrm{P}=0.617)$, prematurity $(\mathrm{P}=0.111)$ and type of labor $(\mathrm{P}=0.132)$.

Parents $<20$ years old or $\geq 35$ years old and having parity $\geq 3$ would be more at risk to have mentally retarded child. New born with asphyxia and born weight $<2500$ grams are also at risk for mental retardationTherefore it is advisable forpeople to avoid the risk of pregnancy by age and medical attention during pregnancy to avoid the occurrence of low birth weight and asphyxia at birth. 
Keywords : Mental retardation, prenatal factor, perinatal factor

\section{INTRODUCTION}

Pregnancy and childbirth is an important phase that passed a woman to become parents. Not all children born with a normal and healthy, some parents actually have a child with intellectualdisabilities or mental retardation. According to the World Health Organization (WHO) mental retardation is a condition in a stuck or incomplete development of the mind characterized by impairment of skills and overall intelligence in areas such as cognitive, language, motor and social skills (WHO, 2001). Mentally retarded child usually has the intelligent quotient (IQ) of less than 70 and occurs before the age of 18 years (America's Children and the Environment,2015).

Mental retardation is a complex issue and problems of the world with major implications, especially for developing countries. Mental retardation is not only seen as a health problem but also a social problem. This is because the IQ owned by people with mental retardation who are below the average, so as their human resources can not be exploited. A total of $0.1 \%$ of these children need care, guidance and supervision throughout his life. Mentally retarded children who can not take care of themselves very dependent on families and communities. So that mental retardation is still a dilemma, a source of anxiety for the family and society (Soetjiningsih, 2013). Irwanto et al. (2010) say that it is still difficult to determine the actual magnitude of the population who have disabilities such as mental retardation, mainly due to changes unlike operational definitions are used. The survey, there are not able to represent well the prevalence of mental disability in the realm of emotional and intellectual (especially Autisma, Attention deficit hyperactivitydisorder, and various other intellectual disabilities).

WHO estimates the number of children with disabilities is about $7-10 \%$ of the total population of children with mental retardation prevalence of between $1 \%-3 \%$ of the entire population (WHO, 2001). Nearly 83 million people worldwide are estimated to have mental retardation, with 41 million has a long-term mental disability. Mental retardation is ranked number four in the list of leading causes of disability (Katiyar and Gupta, 2014).
In Indonesia, children with disabilities that image data vary greatly, there is no current data on the number and conditions of children with disabilities. According to data from the National Statistics Agency in 2007, there were 8.3 million children with disabilities of the total population of children in Indonesia (82.8406 million lives of children), or about $10 \%$. Based on the Social Protection Program Data Collection (PPLS) In 2011, there were 130572 children with disabilities from poor families, and children who have mental retardation was ranked second highest as many as 30460 children (Mujaddid, 2014). People with mental retardation or intellectual disability children 24-59 months based on data Riskesdas in 2010 ranks third after disabled and speech impaired is as much as 0.14\% (Ministry of Health, 2014). Based on data from the Education Department of West Sumatra province in 2017, in the city of Padang there are 37 schools (SLB) both public and private. Students recorded the number of students is 1472 people.

Although more than 2000 causes have been proposed for the mentally retarded, primary etiology remains unclear (Foroutan, 2014). Based on data from the Greenwood Genetic Center, mental retardation can be caused by genetics $(25 \%)$, prematurity $(4 \%)$, the environment (10\%), unknown (60\%) (Srivastava and Schwartz, 2014). Sularyo (2000) also mentions the causes of mental retardation can occur starting from the phase of prenatal, perinatal and postnatal care. Most of the cases the cause is not one, but an interaction between congenital (inherited) and environmental factors. Mental retardation can be caused by multifactorial causes, but many of these factors can be prevented. Given the burden of families and communities must be borne in the management of mental retardation, the effective prevention is the best option. Based on the phenomenon described above, researchers are searching for Prenatal and Perinatal Factors Relationship with Mental Retardation in Children events in Padang Year 2017.

\section{METHODS}

This research is anstudy observational analyticwithdesign. case control study The 
Tabel 1 :Characteristics of respondents by age, education and occupation

\begin{tabular}{|c|c|c|c|c|c|c|c|}
\hline \multirow{2}{*}{ No } & \multirow{2}{*}{ Variable } & \multicolumn{2}{|c|}{ Case } & \multicolumn{2}{|c|}{ control } & \multirow{2}{*}{ Total } & \multirow{2}{*}{$\%$} \\
\hline & & $\mathrm{n}=49$ & $\%$ & $\mathrm{n}=49$ & $\%$ & & \\
\hline \multirow[t]{5}{*}{1} & Educational Status & & & & & & \\
\hline & - No School & 1 & 2 & 1 & 2 & 2 & 2 \\
\hline & - Primary & 13 & 26.5 & 4 & 8.1 & 17 & 17.3 \\
\hline & - Secondary & 22 & 44.9 & 25 & 51 & 47 & 48 \\
\hline & - High & 13 & 26.5 & 19 & 38.8 & 32 & 32.7 \\
\hline \multirow[t]{5}{*}{2} & Work & & & & & & \\
\hline & - Housewife & 39 & 79.6 & 31 & 63.3 & 70 & 71.4 \\
\hline & - entrepreneur & 2 & 4.1 & 5 & 10.2 & 7 & 7.1 \\
\hline & - employees & 8 & 16.3 & 12 & 24.5 & 20 & 20.4 \\
\hline & - Labor & 0 & 0 & 1 & 2 & 1 & 1 \\
\hline
\end{tabular}

population is divided into two, the population of cases (all mothers of mentally retarded children) and a control population (all mothers of normal comparison case: control (1: 1) Data collected by questionnaire. Data analysis was performed using Chi Square.

Tabel 2 : Relationship between prenatal factors and children with mental retardation

\begin{tabular}{|c|c|c|c|c|c|c|c|c|}
\hline \multirow{3}{*}{ Prenatal factor } & \multicolumn{4}{|c|}{ Mental retardation } & \multirow{2}{*}{\multicolumn{2}{|c|}{ Total }} & \multirow{3}{*}{$\begin{array}{c}\text { OR } \\
(95 \% \mathrm{CI})\end{array}$} & \multirow{3}{*}{$p$-value } \\
\hline & \multicolumn{2}{|c|}{ Case } & \multicolumn{2}{|c|}{ Control } & & & & \\
\hline & $\mathbf{f}$ & $\%$ & $\mathbf{f}$ & $\%$ & $\mathbf{f}$ & $\%$ & & \\
\hline \multicolumn{9}{|l|}{ Maternal age } \\
\hline$<20$ and $\geq 35$ & 24 & 49 & 5 & 10,2 & 29 & 29,6 & 8,448 & 0,001 \\
\hline $20-34$ & 25 & 51 & 44 & 89,8 & 69 & 70,4 & $(2,865-24,910)$ & \\
\hline \multicolumn{9}{|l|}{ Paternal age } \\
\hline$<20$ and $\geq 35$ & 29 & 52,2 & 18 & 36,7 & 47 & 48 & 2,497 & 0,043 \\
\hline $20-34$ & 20 & 40,8 & 31 & 63,3 & 51 & 52 & $(1,107-5,634)$ & \\
\hline \multicolumn{9}{|l|}{ Parity } \\
\hline$\geq 3$ & 36 & 73,5 & 20 & 40,8 & 56 & 57,1 & 4,015 & 0,002 \\
\hline$<3$ & 13 & 26,5 & 29 & 59,2 & 42 & 42,9 & $(1,712-9,416)$ & \\
\hline \multicolumn{9}{|l|}{$\begin{array}{c}\text { Maternal } \\
\text { hypertension }\end{array}$} \\
\hline Hypertension & 3 & 6,1 & 1 & 2 & 4 & 4,1 & 3,130 & 0,617 \\
\hline Normal & 46 & 93,9 & 48 & 98 & 94 & 95,9 & $(0,314-31,193)$ & \\
\hline
\end{tabular}

children). The location was chosen for this study is SLB in Padang and elementary school in Padang. The research was conducted in November 2016 - December 2017.The sample size is 49 people taken by cluster sampling by

Table 1 gives the details of the characteristics of the respondents in this study. Highest level of education respondents is secondary education

Table 2 shows that those who have children with mental retardation, there are as many as $49 \%$ of respondents who have a age of at risk during pregnancy. While the group had normal children, there are as many as $10.2 \%$ of respondents who have a age of at risk during pregnancy. The results of statistical tests showed a significant relationship between maternal age during pregnancy with mental retardation events $(p=0.001)$. From the analysis it is known that women with age at risk during pregnancy had 8.4 times the possibility to have children with mental

\section{RESULTS AND DISCUSSION}

The results of this study based on the information collected from respondents through interviews.

(high school) is as much as $48 \%$ and the most of respondents worked as a housewife is as much as $71.4 \%$.

retardation as compared with mothers who did not have a lifespan of risk.

The results are consistent with research Nurochim et al. (2016) conducted in Surakarta that mothers who have a lifespan of at risk during pregnancy is more common in the group of children with mental retardation $(71.4 \%)$ than normal children (32.9\%). It also found a significant relationship between mother's age during pregnancy with the incidence of mental retardation. In that study said that women with age at risk to have 10 times greater risk for 
having children with mental retardation. Pregnancy at an advanced age, especially after age 40 have a worse risk. The results of the same study also looks into the research Cohen et al. (2014) found that children who were born when their mothers over the age of 35 years had a disability rate higher cognitive compared with those born to mothers younger than 30's with a chance of the numbers of disability highest seen in women aged 45 years or more. Research conducted Mann et al. (2013) in South Carolina also found that children with mental retardation are more likely to be born of mothers who have risky ages.

Different results seen in a study in South Jordan (Nafi and Shaheen, 2013) in children with mental retardation of unknown cause. In the study found that the risk of maternal age had no significant effect on mental retardation. In the study reported that $80 \%$ of women respondents in the age range of normal.

The risk of fetal mental retardation related to maternal age comes primarily from preterm labor on the indication complications in the mother (such as hypertension and diabetes), preterm labor spontaneously, impaired fetal growth related to chronic disease in the mother or the gestational multifetal, aneuploidy fetus, and pregnancy obtained with the help of reproductive technology (Cunningham, 2012). Women younger than 20 years were more likely to have anemia, and they are at high risk of having babies with growth restriction, preterm labor experience and have infant mortality rate is higher. Pregnancy elderly, especially after 40 years increases the risk of severe mental retardation or Down's syndrome. Although maternal age correlation with Down syndrome have not managed to explain but most cases are due to fail to separate during meiosis I (Campbell, 2010).

Maternal age old and very young will affect the health of the mother during pregnancy and childbirth. Therefore it is very important for women to know a good age for a pregnancy and the risk of gestational age $<20$ years or $>35$ years. Policy emphasis on improving maternal health and prenatal care is needed to avoid the complications and risks that may occur.

Father's age is at risk when pregnant women are more common in the case group (59.2\%) than the control group $(36.7 \%)$. Statistical test results showed a significant relationship between the age of the father with the incidence of mental $\operatorname{retardation}(p=0.043)$. The results of analysis that the father of the age of 2.5 times at risk have the possibility to have a child with mental retardation compared to fathers who do not have a life of risk.

The same research results seen in the study Bilder et al. (2013) that the age of the father is at risk when pregnant women are more common in the group of children with mental retardation $(30.8 \%)$ than the control group $(20 \%)$. The results showed paternal age> 34 years had a significant relationship to the incidence of mental retardation. Mental retardation relationship with paternal age is associated with a genetic mutation. In research conducted Kong et al. (2012) note that the average number of paternal mutation is substantially higher than the average number of mutations mother. Therefore, variations ofmutations de novo in individuals largely driven by mutations in paternal and the number of mutations increases with increasing paternal age.mutations De novo in older men increases the risk of conditions such as autism spectrum disorder or schizophrenia may be triggered by such mutations.

In a study from the United States obtained a different result. Children who were born when their father in his early 30s had the lowest level of cognitive disability compared with those who were born when their fathers aged under 30 years or older than 35 years. In these studies indicate that the relationship between paternal age and cognitive incompetence is very small and the addition of paternal age not significantly related to cognitive disability or mental retardation. This is probably because the study found that maternal age is much more strongly associated with cognitive disabilities than children with paternal age. (Cohen, 2014). In the study conducted by Arslan et al. (2014) in Minnesota are also found strong evidence for the relationship with the father's age offspring intelligence.

Increased paternal age significantly increases the risk of a new autosomal dominant mutations are spontaneous. This can result in a child with an autosomal dominant disease, such as neurofibromatosis or achondroplasia. This new mutations can produce children who suffer from diseases related to $\mathrm{X}$. This is one of the causes of mental retardation (Cunningham, 2012). Which advanced paternal age is also one of the factors that increase the risk of limb defects and neural tube defects, Down syndrome and autosomal dominant mutations new. Besides men aged less than 20 years old also have a relatively higher 
risk of fathering a child with birth defects (Sadler, 2009).

Based on the results of this research note that the older ( $\geq 35$ years) or the young age of the father $(<20$ years) it will be increasingly at risk to have children with mental retardation. However, in this study the age of the mother during pregnancy also increased and is also shown to correlate with the incidence of mental retardation as a potential confounding effects. In this research note that as many as $72.4 \%$ of children with mental retardation who had a father with risk age was followed by the age of the mother is at risk. Therefore, further research is needed to study more robust design to get rid of these confounding factors.

Most of mothers of children with mental retardation have parity $\geq 3$ as many as $73.5 \%$ while only $40.8 \%$ of normal children who have parity $\geq 3$. Based on the results of this study found significant results between parity with the incidence of mental retardation $(p=0.002)$. From the analysis results showed that mothers with parity $\geq 34.015$ times have the possibility to have a child with mental retardation than women with parity $<3$.

The results are consistent with research conducted by Huang et al., (2016), which get a significant relationship between parity $\geq 3$ with mental retardation. Results The same study also seen in a study conducted by Croen et al. (2001) on children who were born in California. In these studies it is known that women with parity $\geq 3$ found more frequently in mothers of mentally retarded children (37.3\%) compared with normal children $(29.3 \%)$. It also found that children with mental retardai unknown cause are more likely to have mothers with parity greater than three. However, different results seen in the study Bilder et al., (2013) in Utah that did not find a significant association between parity 3 or parity> 4 with mental retardation. This may be caused by the presence of other variables that have a stronger association with mental retardation were found in the area.

Mentally retarded fetal risk associated parity mother came mainly from the indication of complications in the mother. Mothers with high parity are more likely to have problems in pregnancy and childbirth can cause disruption of the transfer of oxygen from mother to fetus, so asphyxia at birth are more likely to occur (Manuaba, 2010). Pregnancy can cause deterioration multiparity tissue elasticity so as to allow the occurrence of aberration or abnormalities of placental growth and fetal growth. This can affect the supply of nutrients and oxygen from the mother to the fetus so the higher parity chance to give birth to babies with asphyxia also higher (Prawirohadjo, 2012).

In this research note that mothers with three or more parity would be more at risk for having children with mental retardation. High maternal parity was associated with problems in pregnancy and childbirth, and asphyxia. In this study also found that $33.3 \%$ were mentally retarded children born to mothers with parity $\geq 3$ asphyxiated. Therefore, it is important to consider confounding risk factors involved.

The children of those who have mental retardation, there are as many as $6.1 \%$ of respondents who had a history of hypertension in pregnancy. While the group had normal children, only $2 \%$ of respondents who had a history of hypertension in pregnancy. Based on test results obtained stasistik there is no significant relationship between a history of hypertension in pregnancy with the incidence of mental retardation $(p=0.617)$.

Similar to this study, the research conducted by Bilder et al., (2013) get only a small percentage of mentally retarded children who had mothers with hypertension in pregnancy (4.1\%). In these studies found that chronic hypertension or hypertension during pregnancy did not have a significant relationship to the incidence of mental retardation. A study conducted by Leonard et al. (2006) in Western Australia have found similar results. The results of such research states that there is no increased risk of significant maternal hypertension to produce offspring with mental retardation, good for mental retardation is mild, moderate or severe.

Different research results seen in the metaanalysis study conducted by Huang et al. (2016) who get a significant relationship between children born to mothers with hypertension incidence of mental retardation. The research result Langridge et al., (2013) on children mildmoderate mental retardation in Western Australia also found that hypertension in pregnancy may increase the risk of children with mild to moderate mental retardation. Although hypertension is a significant factor for mental retardation in both studies above but the strength of the association is low (OR <1.5). Results of different studies with this study might be due to the number of different samples, which the research that gets results relating have the 
Tabel 3 : Relationship between perinatal factors and children with mental retardation

\begin{tabular}{|c|c|c|c|c|c|c|c|c|}
\hline \multirow{3}{*}{ Perinatal factor } & \multicolumn{4}{|c|}{ Mental retardation } & \multirow{2}{*}{\multicolumn{2}{|c|}{ Total }} & \multirow{3}{*}{$\begin{array}{c}\text { OR } \\
(95 \% \quad C I)\end{array}$} & \multirow{3}{*}{$p$-value } \\
\hline & \multicolumn{2}{|c|}{ Case } & \multicolumn{2}{|c|}{ Control } & & & & \\
\hline & $\mathbf{f}$ & $\%$ & $\mathbf{f}$ & $\%$ & $\mathbf{f}$ & $\%$ & & \\
\hline \multicolumn{9}{|l|}{ Gestational age } \\
\hline$<37$ weeks & 6 & 12,2 & 1 & 2 & 7 & 7,1 & 6,698 & 0,111 \\
\hline > 36 weeks & 43 & 87,8 & 48 & 98 & 91 & 92,9 & $(0,775-57,881)$ & \\
\hline \multicolumn{9}{|l|}{ Asphyxia } \\
\hline Asphyxia & 16 & 32,7 & 1 & 2 & 17 & 17,3 & 23,273 & 0,001 \\
\hline Normal & 33 & 67,3 & 48 & 98 & 81 & 82,7 & $(2,942-184,124)$ & \\
\hline \multicolumn{9}{|l|}{ Birth weight } \\
\hline$<2500 \mathrm{~g}$ & 8 & 16,3 & 1 & 2 & 9 & 9,2 & 9,366 & 0,031 \\
\hline$\geq 2500 \mathrm{~g}$ & 41 & 83,7 & 48 & 98 & 89 & 90,8 & $(1,124-78,046)$ & \\
\hline \multicolumn{9}{|l|}{ Mode of delivery } \\
\hline Vaginal & 37 & 75,5 & 29 & 59,2 & 66 & 67,3 & 0,470 & 0,132 \\
\hline Cesarean section & 12 & 24,5 & 20 & 40,8 & 32 & 32,7 & $(0,198-1,117)$ & \\
\hline
\end{tabular}

number of samples very much when compared with the study.

In patients with hypertension, impaired uteroplacental perfusion due to vasoplasme almost certainly a major cause of increased rates of perinatal mortality and morbidity. Chronic hypertension in pregnancy may lead to placental

Table 3 appears there was as much as $12.2 \%$ of children who were born prematurely in case group. Whereas in the control group, only $2 \%$ of children who were born prematurely. Stasistik test results obtainedvalue $>p \quad 0.05(p=0.111)$ means that there is no significant relationship between the incidence of prematurity with mental retardation.

Different results found in studies conducted Heuvelman et al. (2017) in Stockholm, Sweden, who found that preterm birth makes it possible to increase the risk of mental retardation, special education needs, poor school performance and lower IQ in childhood and adulthood. Premature birth can also increase the risk of neurodevelopmental problem long term. In research Onicescu et al. (2014) to the 9402 mothers who have children in South Carolina also found that children who have mental retardation are more likely to be born preterm. Meta-analysis study conducted by Kerr-Wilson et al. (2011) also reported that the relationship between IQ scores with gestation. IQ scores declined constant for each decrease of 1 week during the period of gestation. In the study also linked premature birth with a 12-point reduction in IQ. It is not yet known whether this research applies to cases of ID with different severity levels.

Premature birth is closely related to asphyxia and low birth weight. Infants born preterm are more susceptible to respiratory distress syndrome which can lead to lack of oxygen supply to the abruption, fetal growth restriction and preterm delivery may be a factor causing the baby's brain development disorder (Cunningham, 2012).

baby's brain that can lead to damage to the brain. In addition to respiratory distress syndrome, infants born preterm are also susceptible to intraventricular hemorrhage. This is because the fetus preterm have intracranial blood vessels are fragile so it is vulnerable to bleeding. Intraventricular hemorrhage can result in neurological development of the infant brain (Cunningham, 2012).

The absence of significant influence between prematurity with mental retardation were found in this study could be due to the number of samples is low compared to the above 3 studies that have a large scale. In this study, only a small percentage of mentally retarded children who were born prematurely as many as 6 people $(12.2 \%)$ out of 49 people while in the normal child only 1 (2\%) were born prematurely. However, the results of this study can be seen that more than half of the children who were born prematurely are mentally retarded. In addition, the absence of significant influence between prematurity with mental retardation in this study can also be caused by the influence of other risk factors are more powerful.

Proportion of mentally retarded children have 16 times more likely to asphyxia at birth (32.7\%) than in the group of normal children $(2 \%)$. Stasistik test results obtainedvalue $p<0.05(p=$ 0.001 ) means that there is a significant correlation between the incidence of asphyxia with mental retardation. From the analysis results 
showed that children who experience asphyxia at birth have the possibility of 23.2 times to suffer from mental retardation than children who are not asphyxiated.

Research results are in line with research Bilder et al., (2013) who get their relationship asphyxia with mental retardation with the incidence proportion of $8.2 \%$. In the study asphyxia Apgar score is marked with the first 5 minutes of low and needed resuscitation. Despite the significant results obtained, the condition before birth that affect fetal growth should also be taken into account. The results of the same study also looks into the research Langridge et al. (2013) on children who live in Western Australia. In the study found that neonatal resuscitation have a significant relationship to the incidence of mental retardation.

Newborns are the target group to improve the quality of life of 1000 human day which is also called golden period which if not utilized well there will be permanent damage (Yulizawati, 2016). In the state of asphyxia occur oxygen deficiency in the blood and an increase in carbon dioxide in the blood and tissues. Therefore it can be an injury or failure while several organ systems. When there encephalopathy, usually there is evidence of injury to the majority of other organ systems. Brain damage due to hypoxia can be temporary or permanent depending on the amount of loss of oxygen. In total absence of oxygen will kill brain cells in 18 seconds. Loss of oxygen for longer kill the baby (Gregory, 2006).

Based on the description above, children born with asphyxia would be at greater risk of mental retardation. Therefore, it is necessary to increase the quality of infant asphyxia considering the handling of long-term effects that may occur.

Proportion of children with mental retardation has 8 times more likely to have low birth weight $<2500 \mathrm{~g}(16.3 \%)$ than in the group of normal children (2\%). Stasistik test results obtainedvalue $p<0.05(p=0.031)$ means that there is a significant association between birth weight with the incidence of mental retardation. From the analysis it is known that children with birth weight $<2500 \mathrm{~g}$ had 9.3 times the possibility to have mental retardation than children who had birth weight $\geq 2,500 \mathrm{~g}$.

The results of the same study also looks at research Huang et al. (2016) who get a significant association between low birth weight with the incidence of mental retardation. In the study said that children born with low birth weight are at risk 3.4 times for mental retardation compared with those of normal weight. The same research results obtained by Bilder et al. (2013) who found that low birth weight (> 2500) showed a strong relationship with the incidence of mental retardation, both in the group with genetic kelianan and in the group without genetic kelianan. In the study also found that mentally retarded children are born with low birth weight have 8.3 times the risk for severe mental retardation than children who had normal birth weight. In the study conducted by Mann et al. (2013) in South Carolina also found that children are more likely to have intellectual retardation if they were born with low birth weight.

This is because babies with low birth weight are often caused by premature birth or growth restriction in the womb. In infants with low birth weight caused by premature birth, they are more susceptible to problems such as hypothermia, hypoglycemia, as well as respiratory problems which will affect the baby's brain development. In infants with low birth weight due to growth restriction in the womb, they usually impaired and placental efficiency resulting in lack of oxygen and nutrients chronically in a long time for the growth and development of the fetus including fetal brain development (MOH, 2005). In this study also found that children who have a low birth weight of $87.5 \%$ was also asphyxiated and $50 \%$ were born preterm.

Based on the description above, children born with low birth weight would be at greater risk of mental retardation. But in this study asphyxia also shown to have a significant relationship to mental retardation. In this research note that children with low birth weight of $87.5 \%$ was also asphyxiated. Therefore, further research is needed to study more robust design to get rid of these confounding factors. Given the long-term effects that can happen it is necessary to improve the quality of health services in preventing and dealing with low birth weight babies.

Table 3 shows $24.5 \%$ of mentally retarded children born by means of cesarean section. While in the group of normal children, there are as many as $40.8 \%$ were born by means of cesarean section. Stasistik test results obtainedvalue $>p \quad 0.05(p=0.132)$ means that there is no significant relationship between the type of delivery with the incidence of mental retardation.

According to research conducted by Langridge et al. (2013) say that, compared with spontaneous labor, increased risk of mild- 
moderate mental retardation and severe mental retardation is increased in the emergency section deliveries and deliveries with complications. However, the study did not find any increased risk of mental retardation in a vacuum or forceps delivery. In the cohort study conducted by Bilder et al., (2013) also found an association between birth by cesarean section primary incidence of mental retardation. However, no significant relationship was found between forceps delivery and Vakuum with the incidence of mental retardation. The relationship between primary cesarean section deliveries with mental retardation shown in these studies reflect the inherent risk associated with an indication of cesarean section rather than the procedure itself. Indication of the confounding effect in these variables likelocation sunsang, fetal distress, maternal age, placenta previa, hypertension in pregnancy, maternal fever, CPD, prolap umbilical cord, maternal infections and low birth weight.

The primary section is done on the basis of repeated indications of the contrary is more elective section. In the secondary section confounding effects of fewer and more likely to see labor relations procedure with mental retardation. However, the studies were not obtained relationship between the section is repeated with the risk of mental retardation. Therefore it is necessary to take into account risk factors and indications bully in determining labor relations procedure with mental retardation.

Type of labor may influence the incidence of hypoxia in the fetus as labor sunsang due to the termination of the mother to the fetus of oxygen flow faster or labor latitude that require the use of tools during childbirth that if the fetal head can lead to brain damage. Babies born from cesarean surgery also may also experience difficulty breathing as a result of brain damage suffered. Additionally accelerated delivery can also be hypoxic because the baby is not ready to make breathing through the lungs (Gregory, 2006).

A long and difficult birth will cause severe pressure on the brain to cause bleeding in and around the brain. The effect of this bleeding may be temporary or permanent depending on the severity of the bleeding that occurs. In addition the effects of this bleeding also depend on the part of the brain that is injured (Hurlock, 2013).

There was no significant correlation between labor type and mental retardation. However, in this study, researchers compared only normal labor and delivery with cesarean section. The risk of mental retardation related to the type of labor does not depend on the delivery procedure but depends on the complications in labor. In this study also respondents who gave birth cesarean section also followed by complications such as maternal disease, fetal distress, placenta previa and bleeding.

\section{CONCLUSION}

Parents $<20$ years old or $\geq 35$ years old and having parity $\geq 3$ would be more at risk to have mentally retarded child. Born with asphyxia and born weight $<2500$ grams are also at risk for mental retardationTherefore it is advisable forpeople to avoid the risk of pregnancy by age and medical attention during pregnancy to avoid the occurrence of low birth weight and asphyxia at birth.

\section{ACKNOWLEDGEMENT}

Thanks are given to the Faculty of Medicine and Program S1 Midwifery Faculty of Medicine, University of Andalas,supervisors, academic supervisors, principals and teachers in the field of research and responses that make this research can be done well. 


\section{REFERENCES}

American Psychiatric Association. 2013. Intellectual Disability. DSM-5 Intellectual Disability Fact Sheet. American Psychiatric Publishing. America.

America's Children and the Environment. 2015. Neurodevelopmental Disorders. Third Edition. Updated October 2015.

Arslan, R.C., L.Penke, W.Johnson, W.G.Lacono, dan M. McGue. 2014. The Effect of Paternal Age on Offspring Intelligence and Personality when Controlling for Parental Trait Levels. Plos one 9(2): e90097. doi:10.1371/journal.pone.0090097

Batshaw,M.L.,N.J.Roizen,G.R.Lotrecchiano.2013. Children With Disabilities.7th ed.Paul H Brookes Publishing Co.

Bilder, D.A., J.P. Zimmerman, A.V. Bakian, J.S. Miller, J.T. Dorius, B. Nangle, dan W.M. McMahon. 2013. Prenatal and Perinatal Factors Associated with Intellectual Disability. American Journal On Intellectual And Developmental Disabilities. Vol. 118, No. 2, 156-176.

Campbell, N.A. dan J.B. Reece. 2008. Biology. Eighth Edition. Pearson Education Inc. Terjemahan D.T. Wulandari. 2010. Biologi. Edisi Delapan. Jilid 1. Erlangga. Jakarta.

Cohen, P.N. 2014. Parental Age and Cognitive Disability among Children in the United States. Sociological Science 1: 102-110. DOI: 10.15195/v1.a8

Croen, L.A., J.K. Grether, dan S. Selvin. 2001. The Epidemiology of Mental Retardation of Unknown Cause. PEDIATRICS Vol. 107, No. 6 June 2001.

Cunningham, F.G. 2012. Williams Obstetrics. $23^{\text {rd }}$ Ed. The McGraw Hill Companies. Terjemahan B.U. Pendit, A. Dimantri. Chairunnisa, D.A.Maharani, N. Yesdelita, L. Dwijayanthi, dan W.K. Nirmala. 2012. Obstetri William. Edisi 23. EGC. Jakarta.

Departemen Kesehatan Republik Indonesia. 2005. Pelayanan Kesehatan Neonatal Esensial. Depkes RI. Jakarta

Elfindri, E.Hasnita, Z. Abidin, R. Machmud, dan Elmiyasna.2011. Metodologi penelitian Kesehatan. Baduose Media Jakarta. Jakarta.

Epstein, C.J. 2006. Gangguan Genetik dan Defek Lahir. Dalam Buku Ajar Pediatri Rudolph. Editor A.M. Rudolph, J.I.E. Hoffman, dan C.D. Rudolph. Volume 1. EGC. Jakarta.

Foroutan, M. 2014. Mental Retardation (MR) Etiology in Children Referred to Care Services. Patient Safety \& Quality Improvement journal 2(4):165-167.

Gregori, G.A. 2006. Resusitasi Bayi Baru Lahir. Dalam Buku Ajar Pediatri Rudolph. Editor A.M. Rudolph, J.I.E. Hoffman, dan C.D. Rudolph. volume 1. EGC. Jakarta.

Hamamy, H. 2012. Consanguineous marriages. J Community Genet (2012) 3:185-192. DOI 10.1007/s12687-011-0072-y.

Heuvelman, H., K. Abel, S. Wicks, R. Gardner, E. Johnstone, B. Lee, C. Magnusson, C. Dalman, dan D. Rai. 2017. Gestational age at birth and risk of intellectual disability without a common genetic cause: findings from the Stockholm Youth Cohort. BioRxiv. Doi: http://dx.doi.org/10.1101/129049 doi:

Huang, J., T. Zhu, Y. Qu, dan D. Mu. 2016. Prenatal, Perinatal and Neonatal Risk Factor for Intellectual Disability: A Systemic Review and Meta-Analysis. Plos one 11(4): e0153655.

Hull, D. dan D.I. Johnston. Essential Paediatrics. Third Edition. Pearson Professional Limited. London. Terjemahan H. Gunadi. 2008. Dasar-Dasar Pediatri. Cetakan 1. EGC. Jakarta.

Hurlock, E.B. 2013. Child Development. Sixth Edition. Mc Graw Hill. Terjemahan M.M. Tjandrasa dan M. Zarkasih. Perkembangan Anak. Edisi Enam. Erlangga. Jakarta. 
Irwanto, E.R. Kasim, A. Fransiska, M. Lusli, dan O. Siradj. 2010. Analisis Situasi Penyandang Disabilitas di Indonesia: Sebuah Desk-Review. Pusat Kajian Disabilitas. Universitas Indonesia. Jakarta

Katiyar, J. dan K. Gupta. 2014. Pre-natal and Post-natal Risk Factors for Mental Retardation among Children in Varanasi. Stud Home Com Sci 8(2-3): 101-107.

Kementerian Kesehatan RI. 2014. Penyandang Disabilitas pada Anak. Pusat Data dan Informasi Kementerian Kesehatan RI. Jakarta

Kerr-Wilson, C.O., D.F. Mackay, G.C.S. Smith, dan J.P. Pell. 2011. Meta-analysis of the association between preterm delivery and intelligence. Journal of Public Health. Vol. 34, No. 2, pp. 209216

Kong, A., M. L. Frigge, G. Masson, S. Besenbacher, dan P. Sulem. 2012. Rate of de novo mutations and the importance of father's age to disease risk. Nature 488: 471-475.

Langridge, A.T., E.J. Glasson, N. Nassar, P. Jacoby, C. Pennell, R. Hagan, J. Bourke, H. Leonard, dan F.J. Stanley. 2013. Maternal Conditions and Perinatal Characteristics Associated with Autism Spectrum Disorder and Intellectual Disability. PLOS ONE 8(1): e50963.

Leonard, H., N.D. Klerk, J. Bourke, dan C. Bower. 2006. Maternal Health in Pregnancy and Intellectual Disability in the Offspring: A Population-Based Study. Elsevier. Vol. 16, No. 6:448-454

Lumbantobing, S.M. 2006. Anak dengan Mental Terbelakang. Balai Penerbit FKUI. Jakarta.

Mann, J.R., C. Pan, G.A. Rao, S. McDermott, dan J.W. Hardin. 2013. Children Born to Diabetic Mothers May be More Likely to Have Intellectual Disability. Matern Child Health J (2013) 17:928-932.

Manuaba, IBG. 2010. Ilmu Kebidanan, penyakit Kandungan dan KB untuk Pendidikan Bidan. Edisi 2. EGC. Jakarta

Meadow, R. dan S.J. Newell. 2002. Lecture Notes on Pediatrics. Seventh Edition. Blackwell Science Ltd. Terjemahan K. Hartini dan A.D. Rachmawati. 2005. Lecture Notes Pediatrics. Edisi Ketujuh. Erlangga. Jakarta.

Mujaddid. 2014. Siatuasi Penyandang Cacat: Kesehatan Anak dengan Disabilitas. Buletin Jendela Data dan Informasi Kesehatan. Kementerian Kesehatan RI: 25-30.

Nafi, O.A. dan A.M. Shaheen. 2013. Maternal Age and Consanguinity As Risk Factors for Mental Retardation Among Children In South Jordan. European Scientific Journal 9(8): 1857 - 7881

Notoatmodjo,S. 2010. Metodologi Penelitian Kesehatan. Rineka Cipta. Jakarta

Nurochim, E., D. Indarto, dan A. Prayitno. 2016. Association between Maternal Age at Pregnancy, Socioeconomic Status, Physical Environment, Prenatal, Perinatal, Postnatal History, and the Risk of Mental Retardation. Journal of Maternal and Child Health 1(2): 119-130

Ogata, E.S. 2006. Bayi Dari Ibu Diabetik. Dalam Buku Ajar Pediatri Rudolph. Editor A.M. Rudolph, J.I.E. Hoffman, dan C.D. Rudolph. Volume 1. EGC. Jakarta

Onicescu,G., A.B. Lawson, S. McDermott, C.M. Aelion, dan B.Cai. 2014. Bayesian importance parameter modeling of misaligned predictors: soil metal measures related to residential history and intellectual disability in children. Environ Sci Pollut Res Int. 21(18): 10775-10786. doi:10.1007/s11356-014-3072-8

Prawiroharjo, S. 2012. Ilmu Kebidanan. Jakarta: Yayasan Bina Sarwono Prawirohardjo

Sadler, T.W. 2006. Langman's Medical Embriology. 10 ${ }^{\text {th }}$ Ed. Lippincott Williams \& Wilkins. USA. Terjemahan B.U. Pendit. 2009. Embriologi Kedokteran Langman. Edisi 10. EGC. Jakarta.

Shawky,R.M., S.M.Elsayed, M.E. Zaki, S.M. Nour El-Din, dan F.M.Kamal. 2013. Consanguinity and its relevance to clinical genetics. The Egyptian Journal of Medical Human Genetics (2013)14, 157164. 
Soetjiningsih. 2013. Retardasi Mental. Dalam Tumbuh Kembang Anak. Penyunting soetjiningsih, dan I.N.G. Ranuh. Edisi 2. Penerbit EGC. Jakarta.

Srivastava, A.K. dan C.E. Schwartz. 2014. Intellectual Disability and Autism Spectrum Disorders: Causal Genes and Molecular Mechanisms. Neurosci Biobehav 46(2): 161-174.

Sularyo, T.S. dan M. Kadim. 2000. Retardasi Mental. Sari Pediatri 2(3): 170-177

Wardle, S.P. 2009. Masalah Metabolik, Gangguan Endokrin, dan Putus Obat. Dalam Buku Ajar Bidan Myles. Editor D.M. Fraser, dan M.A. Cooper. Edisi 14. EGC. Jakarta.

World Health Organization. 2016. International Statistical Classification of Diseases and Related Health Problems 10th Revision (ICD-10)-WHO Version for ;2016. http://apps.who.int/classifications/icd10/browse/2016/en\#/F70-F79. 10 Juni 2017 (20:45).

World Health Organization. 2001. Mental and neurological disorders. Fact Sheet: The World Health Report 2001. NMH Communications. Geneva.

Yatchmink, Y. 2006. Keterlambatan Perkembangan : Maturasi yang Tertinggal Hingga Retardasi Mental. Dalam Buku Ajar Pediatri Rudolph. Editor A.M. Rudolph, J.I.E. Hoffman, dan C.D. Rudolph. volume 1. EGC. Jakarta.

Yulizawati., Nurdian.A, Bustami.L.E. Iryani.D, Fitrayeni, dan Insani.A.A. 2016. Family assistance model in the 1000 first day of life using partnership and interprofesional education approach. Journal of Miwifery 1(1): 12-22. 